\title{
Jejaring Sosial dan Diseminasi Teknologi Tepat Guna pada Peternakan Sapi Perah di Daerah Istimewa Yogyakarta
}

\author{
Social Network and Appropriate Technology Dissemination on Dairy Farm in Special Region \\ of Yogyakarta
}

\author{
S. N. W. Mulatmi, A. D. Anggraini dan A. Prima \\ Universitas Muhammadiyah Malang, Jalan Raya Tlogomas 246 Malang, Jawa Timur \\ Corresponding email : septi.mulatmi@gmail.com
}

\begin{abstract}
Appropriate technology must be applied to dairy farming businesses to support business progress so as to increase production optimally. The purpose of this study was to determine the structure of social networking and appropriate technology dissemination in the dairy farmers of the Special Region of Yogyakarta. The research material is 90 dairy farmers in Yogyakarta. The study was conducted using a survey method. The research method used in this research was descriptive analytical method. Social networking at the dissemination was analyzed by Social Network Analysis (SNA) using an analysis tool, Gephi 0.92. Sources of information about appropriate technology come from various parties including family, friends, dairy farmers, veterinarians, cooperative officers, livestock extension agents, employees of milk processing companies, and online media. Dairy farmers in Yogyakarta it is known that the most important source of information about appropriate technology comes from cooperative officers. Cooperative officers are the most trusted source and the main consideration in the decision to adopt technology.
\end{abstract}

Key words: Apropriate technology, social network, dissemination, dairy farm.

\begin{abstract}
ABSTRAK
Teknologi yang tepat guna (TTG) harus diterapkan pada usaha peternakan sapi perah untuk mendukung kemajuan usaha sehingga mampu meningkatkan produksi secara maksimal. Tujuan dari penelitian ini adalah untuk mengetahui struktur jejaring sosial dan diseminasi TTG pada peternak sapi perah di Daerah Istimewa Yogyakarta. Materi penelitian adalah 90 peternak sapi perah di DIY. Penelitian dilakukan dengan menggunakan metode survey. Metode penelitian yang digunakan dalam penelitian ini adalah metode deskriptif analitis. Jejaring sosial dan diseminasi peternakan sapi perah rakyat dianalisis dengan Social Network Analysis (SNA) dengan menggunakan perangkat analisis yaitu Gephi 0.92. Sumber informasi mengenai TTG berasal dari berbagai pihak diantaranya keluarga, teman, sesama peternak, dokter atau mantri hewan, petugas koperasi, penyuluh dari dinas peternakan, pegawai perusahaan pengolahan susu, dan media cetak atau online. Pada peternak sapi perah di DIY diketahui bahwa sumber informasi mengenai TTG yang paling utama adalah berasal dari petugas koperasi. Petugas koperasi adalah sumber yang paling dipercaya oleh peternak dan menjadi pertimbangan utama dalam keputusan melakukan adopsi TTG.
\end{abstract}

Kata kunci: Teknologi Tepat Guna, jejaring social, diseminasi, peternakan sapi perah

\section{PENDAHULUAN}

Teknologi yang tepat guna (TTG) harus diterapkan pada usaha peternakan sapi perah untuk mendukung kemajuan usaha sehingga mampu meningkatkan produksi secara maksimal. Pengetahuan beternak secara tradisional sangat penting untuk pengamanan pangan dan sistem pertanian jangka panjang, namun inovasi teknologi dan pengetahuan modern perlu dimanfaatkan dan disinergikan dengan pengetahuan lokal yang merupakan aset dalam rangka membangun pertanian yang berkelanjutan, karena pada dasarnya kedua pengetahuan itu komplementer (Mulatmi et al., 2016).

Prokopy et al. (2015) menemukan adopsi manajemen atau teknologi terbaik tergantung pada pemanfaatan jejaring sosial. Namun, orang terkadang tidak menyadari pengaruh norma subyektif dan keyakinan normatif pada tindakan mereka dan ada kecenderungan menyangkal pengaruh orang lain. Secara umum, orang-orang menyangkal 
pengaruh orang lain ketika ditanya mengenai teknologi. Namun, tidak dapat dipungkiri bahwa adopsi inovasi didasari mengamati proses dari orang-orang pada lingkungan sosial terdekat. Praktik manajemen yang dapat diamati oleh orang lain lebih mungkin untuk diadopsi dan kemudian dapat didifusikan terhadap orang sekitar (Nolan et al., 2008).

Metode mapan konseptualisasi perubahan di tingkat peternak adalah pendekatan difusi inovasi Roger. Rogers (1995) menyatakan bahwa ada lima tahap dimana inovasi diadopsi: pengetahuan, persuasi, keputusan, implementasi, dan konfirmasi. Peternak terkena inovasi selama tahap awal adopsi, tetapi tidak termotivasi untuk belajar lebih banyak tentangnya; setelah itu, individu menjadi tertarik dan secara aktif mencari informasi; di tahap ketiga adalah keputusan adopsi dibuat; pada tahap keempat inovasi diimplementasikan (dengan derajat yang berbeda-beda) dan akhirnya keputusan dibuat sepenuhnya mengimplementasikan inovasi. Namun, adopsi teknik manajemen yang kompleks mungkin tidak mengikuti pola yang diprediksi oleh difusi.

Ginting (2006) melaporkan bahwa salah satu faktor penyebab sulitnya adopsi teknologi oleh peternak adalah faktor teknis. Pengaruh teknologi terhadap perbaikan hasil dan/atau pendapatan/keuntungan usaha ternak belum diyakini benar oleh peternak. Hal ini disebabkan kurangnya jaringan informasi dan infrastruktur yang tidak mendukung kelancaran masuknya informasi dan ilmu pengetahuan dari luar bagi peternak.

Sumber informasi mengenai TTG bagi peternak berasal dari berbagai pihak, seperti: Penyuluh (PPL), Peneliti/Penyuluh BPTP, Petugas Dinas Peternakan, dan dari sesama peternak. Selain itu, anjuran mengenai TTG didominasi oleh upaya pengenalan oleh penyuluh dan PPL. Pembelajaran sesama peternak terlihat masih sangat rendah, mungkin karena pendidikan mereka yang tidak banyak berbeda, dan diantara mereka tidak ada yang menonjol prestasinya. Namun, apabila ada peternak yang lebih maju di setiap lokasi maka dapat dijadikan sumber informasi bagi peternak sekitarnya.

Tujuan dari penelitian ini adalah untuk mengetahui struktur jejaring sosial dan diseminasi teknologi tepat guna (TTG) pada peternak sapi perah rakyat Daerah Istimewa Yogyakarta.

\section{MATERI DAN METODE}

Materi penelitian adalah 90 peternak sapi perah rakyat di DIY. Pemilihan DIY sebagai lokasi penelitian dikarenakan termasuk dalam provinsi dengan populasi sapi perah tertinggi di Indonesia. Penelitian dilakukan pada bulan Januari sampai Februari 2017. Penelitian dilakukan dengan menggunakan metode survey. Metode penelitian yang digunakan dalam penelitian adalah metode deskriptif analitis. Pengambilan sampel dilakukan dengan menggunakan metode purposive sampling. Data dikumpulkan dengan menggunakan metode wawancara, observasi, dan pencatatan terkait dengan aktivitas diseminasi TTG. Jejaring sosial dan diseminasi pada peternakan sapi perah dianalisis dengan Social Network Analysis (SNA) dengan menggunakan perangkat analisis yaitu Gephi 0.92 .

\section{HASIL DAN PEMBAHASAN}

\section{Karakteristik Responden}

Karakteristik responden pada peternakan sapi perah di DIY dapat dilihar pada Tabel 1. Berdasarkan hasil penelitian diketahui karakter responden seperti umur, pengalaman, pendidikan formal, dan skala usaha peternakan. Rata-rata umur peternak sapi perah di DIY adalah 50,97 tahun. Mulatmi et al. (2016) menyatakan bahwa peternak sapi perah rakyat yang tergolong dalam usia produktif mempunyai potensi yang besar untuk dapat melakukan adopsi inovasi yang kemudian akan berpengaruh pada pengembangan pengetahuan dan keterampilannya dalam pemeliharan sapi perah. Hal ini kemudian diharapkan mampu 
meningkatkan kualitas dan kuantitas produk yang dihasilkan.

Tabel 1. Karakteristik peternak sapi perah di DIY (Daerah Istimewa Yogyakarta)

\begin{tabular}{lll}
\hline \multirow{2}{*}{ Keterangan } & \multicolumn{2}{l}{ DIY } \\
\cline { 2 - 3 } & Jumlah & $\%$ \\
\hline \multicolumn{2}{l}{ Kelompok umur (tahun) } \\
$15-23$ & 0 & 0 \\
$24-32$ & 4 & 4,44 \\
$33-41$ & 12 & 13,33 \\
$42-50$ & 34 & 37,78 \\
$51-59$ & 19 & 21,11 \\
$60-68$ & 16 & 17,78 \\
$69-77$ & 5 & 5,56 \\
$78-86$ & 0 & 0 \\
Rata-rata & $50,97 \pm 10,31$ & \\
Pendidikan formal (tahun) & \\
Tidak sekolah & 15 & 16,67 \\
SD & 43 & 47,78 \\
SMP & 10 & 11,11 \\
SMA & 21 & 23,33 \\
Perguruan tinggi & 1 & 1,11 \\
Pengalaman Beternak (tahun) & \\
$1-5$ & 9 & 10,0 \\
$6-10$ & 18 & 20,0 \\
$11-15$ & 15 & 16,7 \\
$16-20$ & 17 & 18,9 \\
$21-25$ & 11 & 12,2 \\
$>25$ & 20 & 22,2 \\
Rata-rata & $19,27 \pm 11,15$ & \\
Kepemilikan & Ternak & \\
$0,01-4$ & 58 & 64,4 \\
$4,01-8$ & 28 & 31,1 \\
$8,01-12$ & 4 & 4,4 \\
$12,01-16$ & 0 & 0 \\
$16,01-20$ & 0 & 0 \\
$>20$ & 0 & 0 \\
Rata-rata & & $3,73 \pm 2,20$ \\
\hline \multicolumn{3}{c}{}
\end{tabular}

Rata-rata pendidikan formal yang dijalani oleh peternak sapi perah di DIY adalah 6 tahun. Pengadopsi Teknologi Tepat Guna (TTG) dalam masyarakat terutama dilakukan oleh orang-orang yang berpendidikan tinggi. Terlihat ada keterkaitan antara tingkat pendidikan dengan difusi dan adopsi TTG. Sebagian besar peternak sapi perah tidak berpendidikan atau telah memperoleh sedikit pendidikan; bahkan ada sebagian peternak yang putus sekolah dasar. Selain itu, tinggal di pedesaan membuat para peternak hanya memiliki sedikit akses ke teknologi modern dan pasar yang kompetitif, sehingga difusi dan adopsi teknologi menjadi lamban (Utaranakorn and Yasunobu, 2016).

Rata-rata pengalaman beternak sapi perah di DIY adalah 19,27 tahun. Koentjaraningrat (1979) menyatakan bahwa pengalaman merupakan salah satu faktor yang mempengaruhi maju mundurnya usaha. Peternak yang belajar dari pengalaman dan pelatihan-pelatihan akan mendapat pedoman usaha yang lebih baik dan mampu mengatasi hambatan-hambatan yang terjadi. Rata-rata kepemilikan ternak sapi perah di DIY adalah 3,73 UT. Mardikanto (2009) menyatakan bahwa semakin luas usaha seseorang, maka semakin cepat mengadopsi teknologi baru karena memiliki ekonomi yang lebih baik.

\section{Sumber informasi TTG}

Informasi mengenai TTG yang sering diterima peternak berasal dari beberapa sumber antara lain dinas pertanian, penyuluh, kelompok ternak, peternak lain, keluarga, maupun media massa. Sumber informasi dan pengukuran centrality pada peternakan sapi perah rakyat di DIY dapat dilihat pada Tabel 2. Studi ini membantu dalam menggambarkan aliran informasi utama jalur yang terkait dengan TTG dengan mengidentifikasi pola yang berbeda hubungan sosial dan menganalisis jejaring sosial peternak. Ini bisa menjadi langkah awal untuk membangun yang efektif dan efisien sistem penyampaian informasi memberikan andal dan bermanfaat informasi kepada peternak.

Manajemen, termasuk di dalamnya penggunaan teknologi membutuhkan pemahaman tidak hanya sumber informasi yang peternak gunakan, tetapi juga bagaimana dan mengapa mereka memilih sumber-sumber ini, apakah mereka percayai mereka, dan bagaimana mereka menggabungkan sumber-sumber ini dengan informasi lain untuk menginformasikan keputusan mereka. Sumber informasi mengacu pada sumber-sumber sosial yang 
secara langsung merekomendasikan strategi manajemen untuk usaha para peternak, seperti ekstensi universitas, penasihat tanaman sektor swasta, dan pemasok benih dan pupuk (Stuart et al., 2018).

Peternak yang diwawancarai menjelaskan bahwa mereka tidak bergantung pada salah satu sumber informasi, melainkan menggabungkan sumber informasi. Wawancara mengungkapkan bagaimana peternak menimbang dan menggabungkan informasi dari sumber-sumber ini dengan cara yang berbeda. Beberapa peternak terutama mengandalkan pada penasihat dari sisi koperasi, sementara yang lain menggunakan lebih banyak sumber public termasuk rekomendasi dari dinas terkait. Beberapa peternak yang diwawancarai memiliki peringkat atau urutan pribadi dimana mereka berkonsultasi dengan sumber dan memprioritaskan informasi dalam pengambilan keputusan. Secara keseluruhan, pandangan berbagai saluran informasi bervariasi di antara peternak, seperti halnya frekuensi penggunaan sumber informasi tertentu.

Penelitian oleh Stuart et al. (2018) telah menunjukkan ketergantungan peternak pada sumber informasi eksternal dan kemungkinan hubungan antara perilaku dan informasi sumber. Belum diketahui tentang bagaimana peternak memahami dan memanfaatkan rekomendasi dari para sumber dan mengapa mereka lebih suka sumber spesifik lebih dari yang lain. Jenis informasi yang dicari peternak mungkin juga berperan dalam sumber informasi apa yang mereka andalkan. Sumber-sumber informasi publik diketahui lebih dipercaya ketika peternak tertarik pada masalah yang berhubungan dengan pengingkatan produktivitas ternak. Peternak menggunakan banyak sumber informasi dan menyatakan bahwa ada sumber informasi yang lebih dipercaya dari sumber informasi yang lain.

Kepercayaan khusus berdasarkan pada hubungan pribadi dengan seorang individu adalah faktor penting dalam menentukan penggunaan informasi. Peternak menyebutkan individu yang terkait dengan sumber-sumber ini yang telah mereka kenal selama bertahun-tahun, disukai secara pribadi, dan dipercaya. Mengembangkan kepercayaan khusus membutuhkan waktu dan banyak peternak mencatat bertahuntahun mereka mengenal individu yang mereka percayai (Utaranakorn and Yasunobu, 2016).

\section{Keluarga, Tetangga, Teman sesama Peternak}

Berdasarkan hasil wawancara,
diketahui bahwa peternak banyak menggunakan informasi dari keluarga, teman, dan tetangga yang sebagian besar berprofesi sebagai peternak. Hasil penggunaan informasi dapat dilihat pada Tabel 2.

Para peternak yang diwawancarai menunjukkan bahwa berkomunikasi dengan tetangga dan teman-teman peternak adalah sumber utama informasi yang membimbing penggunaan TTG. Beberapa peternak mungkin tidak berkomunikasi secara langsung mengenai TTG tetapi peternak belajar dari mengamati langsung praktik sesame peternak. Peternak secara selektif memilih dan menggunakan informasi dari peternak. Peternak yang diwawancarai juga menyatakan bahwa anggota keluarga yang juga beternak tetap menjadi sumber informasi tepercaya. Informasi yang lebih dipercaya berasal dari anggota keluarga yang telah beternak selama bertahun-tahun. Beberapa peternak menyebut keluarga sebagai yang paling penting dalam proses pengambilan keputusan untuk melakukan keputusan adopsi TTG. Sedangkan, peternak lain menjelaskan bagaimana sebuah keluarga mengajarkan banyak pengalaman, pengetahuan, dan kepercayaan dalam pengambilan keputusan terutama mengenai TTG.

\section{Pegawai Koperasi}

Sumber informasi lain yang dipercaya oleh peternak berasal dari anggota kelompok fungsional yang operasional di sebagian besar penelitian lokal; ini lebih dikonsultasikan daripada sumber-sumber lain seperti pedagang input lokal atau pejabat 
koperasi susu. Berdasarkan hasil penelitian diketahui bahwa keterlibatan dan keanggotaan dalam organisasi berbasis susu, seperti koperasi susu, akan menciptakan dialog yang bermakna antara peternak anggota koperasi khususnya untuk penyebaran TTG.

\section{Dokter Hewan/Mantri Hewan}

Dokter hewan dan mantri hewan cukup sering ditemui oleh peternak. Para peternak menganggap para dokter hewan maupun mantri hewan memiliki pengetahuan yang lebih banyak, dan dapat menjadi salah satu pertimbangan penting dalam pengambilan keputusan teknologi. Para peternak sapi perah mendapatkan informasi mengenai pengembangan usaha peternakan sapi perah yang dimilikinya dari berbagai sumber informasi yang tersedia, baik sumber informasi formal dan sumber informasi informal. Salah satu sumbernya adalah dokter hewan, yang memberikan informasi mengenai teknologi inovasi peternakan seperti IB dan kesehatan ternak, khususnya sapi perah.

\section{Dinas Pertanian-Peternakan}

Lembaga penyuluh harus dapat mengidentifikasi dan mengatur alternatif bagi mitra penyuluh untuk menyediakan informasi tentang TTG. Sebagai pendidik penyuluh harus mampu meningkatkan pengetahuan dan wawasan para peternak sehingga mereka bisa mendapatkan informasi yang berguna dan mutakhir mengenai perkembangan dan teknik-teknik peternakan. Peranan penyuluh sebagai fasilitator adalah mendukung terselenggaranya proses pembelajaran peternak dengan baik. Tjitropranoto (2003) mengemukakan bahwa penyuluh yang diharapkan saat ini tidak cukup hanya sebagai penyedia atau penyampai informasi semata, tetapi lebih diperlukan sebagai motivator, dinamisator dan fasilitator.

\section{Perusahaan Pengolahan Produk Peternakan}

Sebagian besar peternak menggunakan informasi dari pegawai perusahaan pengolahan produk peternakan, dalam hal ini pengolahan susu. Pegawai perusahaan yang sering datang berkunjung sering menyampaikan mengenai teknologi baru yang baik digunakan untuk meningkatkan kualitas susu. Selain itu, para peternak sering meminta saran dan masukan dari pegawai perusahaan mengenai TTG. Saran serta masukan dari pegawai perusahaan kemudian digunakan sebagai pertimbangan untuk penggunaan TTG.

\section{Sumber Lain}

Media massa adalah salah satu sumber informasi yang digunakan oleh peternak. Media massa dapat dimanfaatkan untuk menambah ekstensi formal dan dapat menciptakan kesadaran yang lebih baik tentang teknologi di antara peternak dan profesional. Media massa yang digunakan tidak hanya berasal dari media cetak, tetapi juga dari media online. Peternak diketahui mengumpulkan informasi dari media peternakan dan sumber online. Peternak yang disurvei dilaporkan menggunakan majalah pertanian atau media lain sering atau sangat sering.

\section{Centrality}

$\begin{array}{llr}\text { Scott } & (2000) & \text { mendefinisikan } \\ \text { centrality } & \text { sebagai } & \text { pengukur yang }\end{array}$ menghasilkan perkiraan kasar dari social power sebuah node berdasarkan seberapa baik node tersebut terkoneksi di dalam jaringan. Semakin besar nilai social power dari sebuah node, menandakan node tersebut memiliki andil yang cukup besar dalam pendistribusian informasi. Berdasarkan hasil penelitian diketahui bahwa degree centrality untuk keluarga, teman dan tetangga peternak adalah 50. Degree centrality digunakan untuk mengetahui banyaknya peternak yang menggunakan informasi dari sesame peternak. Hasil ini dapat dikatakan tinggi, dan hasilnya persebarannya dapat dilihat pada Gambar 1.

Hasil analisis jejaring sosial, menampilkan jaringan afiliasi antara peternak dan sumber informasi. Strukturnya adalah berdasarkan pada tanggapan mereka mengenai sumber informasi mereka yang 


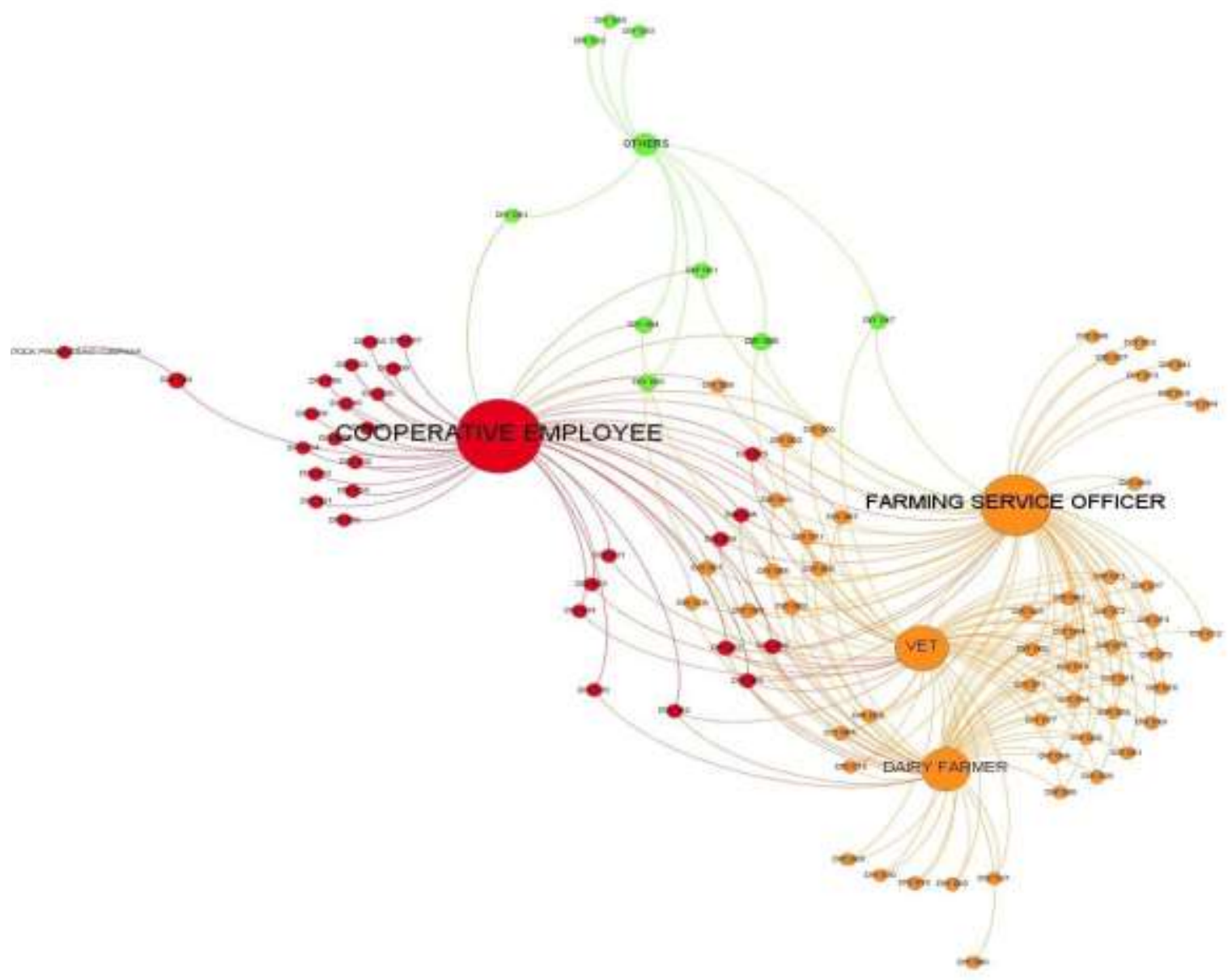

Gambar 1. Jejaring sosial dan persebaran informasi pada peternak sapi perah di DIY.

paling penting dan paling sering digunakan. Beberapa responden memiliki sumber informasi tunggal sementara beberapa memiliki banyak, terbukti dari jumlah mereka hubungan sosial. Lebih banyak sumber informasi peternak dipengaruhi oleh besar atau tidaknya jejaring social yang dimiliki oleh peternak tersebut. Ini artinya peternak dengan banyak kontak dalam jaringan akan membentuk keputusan teknologinya berdasarkan kombinasi informasi dari berbagai sumber. Frekuensi ikatan sosial dari berbagai sumber informasi jaringan di berbagai daerah menunjukkan bahwa pegawai koperasi, penyuluh peternakan, dokter hewan dan sesame peternak adalah sumber informasi untuk responden.
Persuasi dan pengaruh sosial yang dihasilkan dari kontak sosial proksimal spasial mungkin memiliki peran penting dalam diseminasi TTG. Memanfaatkan jaringan lokal yang kuat merupakan jalan yang lebih menjanjikan untuk menyebarkan informasi, memfasilitasi pembelajaran, dan penerapan adopsi teknologi yang lebih baik. Bahkan, bukti penelitian menunjukkan bahwa layanan penyuluhan dapat mempromosikan teknologi baru dengan memanfaatkan jejaring social (Vishnu, 2018) Pengukuran sentralitas sumber informasi dari berbagai jaringan dihitung untuk melihat dominasi mereka dan pengaruh dalam jaringan ini. Hasil penelitian mengenai centrality disajikan pada Tabel 2 . Tingkat sentralitas sumber informasi diperoleh untuk semua jaringan. Ukurannya 
Tabel 2. Pengukuran centrality sumber informasi peternakan sapi perah rakyat di DIY.

\begin{tabular}{llll}
\hline \multirow{2}{*}{ Sumber informasi } & \multicolumn{3}{c}{ Pengukuran Centrality } \\
\cline { 2 - 4 } & $\begin{array}{l}\text { Degree } \\
\text { Centrality }\end{array}$ & $\begin{array}{l}\text { Betwenness } \\
\text { Centrality }\end{array}$ & $\begin{array}{l}\text { Closeness } \\
\text { Centrality }\end{array}$ \\
\hline Keluarga/Teman/Tetangga & 50 & 908,19 & 0,52 \\
Pegawai Koperasi & 45 & 1849,76 & 0,5 \\
Dokter Hewan/Mantri Hewan & 51 & 991,81 & 0,53 \\
Dinas Pertanian-Peternakan & 56 & 1454,77 & 0,56 \\
Perusahaan Pengolahan Produk Peternakan & 1 & 0,0 & 0,41 \\
Lainnya & 9 & 295,44 & 0,40 \\
\hline
\end{tabular}

merupakan indikasi dari jumlah tautan informasi langsung untuk para pelaku informasi dalam jaringan. Seperti dapat dilihat dalam Tabel 2, petugas koperasi memiliki betwenness centrality tingkat tertinggi di DIY, yaitu 1849,76, menunjukkan mereka secara signifikan berperan sebagai sumber informasi yang paling disukai oleh responden. Scott (2000) menyatakan bahwa Betweeness Centrality adalah ukuran yang memperlihatkan peran sebuah node menjadi bottleneck. Node menjadi penting jika menjadi communication bottleneck. Ukuran ini juga dapat digunakan untuk mengidentifikasi boundary spanners, yaitu orang atau node yang berperan sebagai penghubung (jembatan) antara dua komunitas.

Penyuluh peternakan dari Dinas peternakan di DIY memiliki skor antara tertinggi dalam hal closeness centrality, yaitu 0,56 . Hal ini menyatakan bahwa peran penyuluh sangat kuat sebagai titik masuk atau kunci fasilitator yang menghubungkan berbagai sumber informasi sebagai satu jaringan. Scott (2000) menyatakan bahwa closeness centrality menunjukkan ukuran berbagai daerah dihitung. Seorang sumber informasi dengan closeness centrality tinggi akan terkait erat dengan banyak pihak, dengan demikian berada dalam posisi untuk menerima informasi dari berbagai sumber daya lain dari jaringan.

\section{KESIMPULAN}

Berdasarkan hasil penelitian diketahui bahwa jejaring sosial pada peternakan sapi perah sangat penting dalam persebaran informasi mengenai TTG. Sumber informasi mengenai TTG berasal dari berbagai pihak diantaranya keluarga, teman, sesama peternak, dokter atau mantri hewan, petugas koperasi, penyuluh dari dinas peternakan, pegawai perusahaan pengolahan susu, dan media cetak atau online. Pada peternak sapi perah di DIY diketahui bahwa sumber informasi mengenai TTG yang paling utama adalah berasal dari petugas koperasi. Petugas koperasi adalah sumber yang paling dipercaya oleh peternak dan menjadi pertimbangan utama dalam keputusan melakukan adopsi TTG.

\section{SARAN}

Penelitian lebih lanjut diperlukan untuk lebih memahami bagaimana dan mengapa peternak lebih suka, menggabungkan, dan memanfaatkan sumber informasi spesifik memandu keputusan mereka tentang aplikasi teknologi.

\section{DAFTAR PUSTAKA}

Ginting, Paham, 2006. Filsafat Ilmu dan Metode Penelitian, USU Press, Medan

Koentjaraningrat. (1979). Pengantar Ilmu Antropologi. Jakarta: Aksara Baru.

Mardikanto, T. 2009. Sistem Penyuluhan Pertanian. Sebelas Maret University Press. Surakarta.

Mulatmi, S.N.W., B. Guntoro, B. P. Widyobroto, S. Nurtini, A Pertiwiningrum. 2016. Strategi Peningkatan Adopsi Inovasi pada Peternakan Sapi Perah Rakyat di Daerah Istimewa Yogyakarta, Jawa 
Tengah, dan Jawa Timur. Buletin Peternakan. 40 (3): 219-227.

Nolan, J. M, P. Wesley Schultz, Robert B. Cialdini, Noah J. Goldstein, Vladas Griskevicius. 2008. Normative Social Influence is Underdetected. Sage Journal. 34 (7): 913-923.

Prokopy, L.S., J. S. Carlton, J. G. Arbuckle Jr., T. Haigh, M. C. Lemos, A. S. Mase, N. Babin, M. Dunn, J. Andresen, J. Angel, C. Hart, R. Power. 2015. Extension's role in disseminating information about climate change to agricultural stakeholders in the United States. Clim. Change 130: 261-272.

Rogers, E. 1995. Difussion of Innovations (Fifth Edition). Free Press. New York, London, Toronto, Sidney.

Scott, J. (2000). Social network analysis: A handbook. London: Sage Publications.

Stuart, D., R.C. H. Dennyb, M. Houserb, A.P. Reimerc, S. Marquart-Pyattd. 2018.
Farmer Selection of Sources of Information for Nitrogen Management in the US Midwest: Implications for Environmental Programs. Land Use Policy 70: 289-297.

Tjitropranoto, P. 2003. Penyuluhan Pertanian Masa Kini dan Masa Depan, Dalam Membentuk Pola Perilaku Manusia Pembangunan, Disunting Ida Yustiana dan Adjat Sudrajat. IPB Press.

Utaranakorn P., K. Yasunobu. 2016. The mutual influence of managerial ability and social networks of farmers on participation in an organic vegetable group in Khon Kaen province, Thailand. Kasetsart Journal of Social Sciences. 37: 127-131.

Vishnu S., J. Gupta. S.P. Subash. 2018. Social Network Structures among the Livestock Farmers Vis A Vis Calcium Supplement Technology. Information Processing in Agriculture $\mathrm{xxx}$. 